\title{
Fashioning a future Part II: Romanticism and conservation in the European colonisation of Otago, $1840-60^{1}$
}

\author{
JAMES BEATTIE \\ The Centre for Science in Society, Victoria University of Wellington, \\ Aotearoa New Zealand; Research Associate, Centre for Environmental History, \\ The Australian National University, Australia; Senior Research Associate, \\ Faculty of Humanities, University of Johannesburg, Republic of South Africa; \\ Senior Research Associate, World Centre for Environmental History, \\ Sussex University, United Kingdom
}

\section{Abstract}

This two-part article examines environmental attitudes and actions amongst the first generation of settlers in Otago, New Zealand, between 1840 and 1860 . Based on extensive analysis of diaries, letters, artworks and official documents, it argues for the need to recognise the complexity of European environmental responses and actions, including highlighting extensive official attempts at forest conservation from the late 1840s. Part I of this article demonstrated the importance of the concept of improvement, which impelled Otago colonists to introduce familiar plants and animals, establish farms and engage in largescale environmental modification. Part II is in two sections: Section 1 considers the impact of Romanticism on settler interpretations of Otago's environment, including on how they framed and depicted its harbours and mountains in writing and art. Section 2 examines concerns over resource depletion and details official measures to protect forests, including reservation, licensing of timber extraction and the appointment of forest guards. Section 3 analyses urban environmental conflict in Dunedin's Town Belt.

Keywords: environmental history, colonisation, Otago, conservation, urban environmental history, forest history, Romanticism, Dunedin Town Belt

\footnotetext{
1 This article relies on research conducted in 1999, 2006 and 2019-20. I would like to thank Jenny Chen, archivist, Toitū Otago Settlers Museum, and her predecessors Emma Knowles, Jill Haley and Tania Connelly for their enthusiasm and help, as well as Séan Brosnahan, Claire Orbell and Pete Read, also of Toitū Otago Settlers Museum, and Austin Gee. The MS has benefited immensely from the comments of Michael Reilly, Mike Roche, Liz Sherwood, Paul Star and Johnny West. I also thank, for helpful conversations, Tom Brooking, Gerard O'Regan, Eric Pawson, Megan Potiki, Mike Stevens, Ryan Tucker Jones, Richard Walter and Graeme Wynn.
} 
Part I of this article, published in Volume 6, Issue 2 of International Review of Environmental History, examined settler environmental attitudes and actions in Otago between 1840 and 1860. Part II of the article considers the impact of Romanticism on settler interpretations of Otago's environment, including on the way they depicted its harbours and mountains in writing and art (Section 1). Section 2 examines settler attempts to conserve resources, mainly forests. Section 3 analyses resource conflict and conservation of Dunedin's Town Belt. In discussing European environmental beliefs and actions, this article does not focus specifically on the Kāi Tahu experience of environment-this is examined in a number of other fascinating studies. ${ }^{2}$

The present study engages, in particular, with Paul Star's revisionist work on European environmental actions and attitudes in Dunedin. Star's article, which focuses on the period after 1868, reveals a complex set of European attitudes and actions towards indigenous nature. In particular, his findings, while revealing considerable environmental destruction, challenged characterisations of 'nineteenthcentury Europeans in New Zealand ... as uncaring pioneers, who feared or hated the bush and who wrote off native species as biologically bound for extinction'. ${ }^{3}$ The second work to which this study responds is Neil Clayton's dissertation of 1998. Clayton's writing explores mismatches between environmental assessment of Otago's resources and early Otago land legislation. ${ }^{4}$ Clayton's work, as well as my own from 1999, touches on early forest conservation efforts. ${ }^{5}$ This article amplifies the earlier findings of Star, Clayton and myself by demonstrating greater awareness and attempts at forest conservation than all three of us were aware of, as well as highlighting considerably different approaches to conservation. The extent and early timing of European conservation, I later show, creates a need to rewrite conservation histories of European settlement to acknowledge their longer-term trajectory.

\footnotetext{
2 Khyla J. Russell, 'Landscape: Perceptions of Kai Tahu I Mua, Āianei, Ā Muri Ake' (PhD diss., University of Otago, 2000); Atholl Anderson, The Welcome of Strangers: An Ethnohistory of Southern Maori A.D. 1650-1850 (Dunedin: Otago University Press, 1998); Jonathan West, The Face of Nature: An Environmental History of the Otago Peninsula (Dunedin: Otago University Press, 2017); Michael J. Stevens, 'Kāi Tahu me te Hopu Tìtī ki Rakiura: An Exception to the "Colonial Rule"?', Journal of Pacific History 41, no. 3 (December 2006): 273-91, doi.org/ 10.1080/00223340600984737. On disease and public health: Pamela Wood, Dirt: Filth and Decay in a New World Arcadia (Dunedin: Otago University Press, 2005).

3 Paul Star, 'New Zealand's changing natural history. Evidence from Dunedin, 1868-1875', New Zealand Journal of History, 32, no. 1 (1998): 69.

4 Neil Clayton, 'Settlers, politicians and scientists: Environmental anxiety in a New Zealand colony' (Post-Graduate Diploma in Arts diss., University of Otago, 1998).

5 James Beattie, 'Lusting after a lost arcadia: European environmental perception in the Otago area, 1840-1860' (BA Hons. diss., University of Otago, 1999).
} 


\section{Romanticism}

Here in Otago there are scenes of natural beauty that realize the conceptions of a [Claude] Lorraine, and of which without the hand of the artist I could convey to you but little idea. Indeed I feel assured that a good artist transmitting views of the country, might do more in conveying a knowledge of it to the people at home. ${ }^{6}$

Letter from unnamed Otago settler, 1851

Otago's colonisation, as noted in Part I, was strongly rooted in Romanticism through a desire to escape the evils of cities and shake off the fetters of mechanisation. Instead, settlers sought to plant a community of god-fearing, hard-working farmers, and to establish a pre-industrial mode of life. As a 'mood rather than a movement', Romanticism fanned out across the Anglo-world with European colonisation, shaping everything from fashion, art, writing and intellectual life to the way Europeans regarded non-Europeans and environments. ${ }^{7}$ While some have characterised Romanticism as a reaction to the eighteenth-century Enlightenment's cool reason and cold objectivity, ${ }^{8}$ in reality Romanticism 'did not complicate the Enlightenment's legacy', but accepted science as a means of exalting national destiny and of regenerating the passions. ${ }^{9}$ Romantics essentially combined 'cool intelligence and warm, troubled emotion'. ${ }^{10}$

\section{Historiography on romanticism}

Romanticism has received some attention from environmental historians and historical geographers of Aotearoa New Zealand. As noted in Part I of this article, Paul Shepard's 1969 study of pre-1850 European views examined Romanticism, but almost totally overlooked the South Island. ${ }^{11}$ In 1990 his fellow historical geographer Judith Johnston argued that settlers initially saw the New Zealand landscape in romantic terms, but, following settlement, viewed it within a more

\footnotetext{
6 'Letters from settlers 1', Dunedin, 5 May 1851, in Otago Journal 8 ([1851]), 120.

7 The Cambridge Cultural History, vol. 6: The Romantic Age in Britain, ed. Boris Ford (Cambridge: Cambridge University Press, 1992).

8 Charles Breunig, The Age of Revolution and Reaction 1789-1850 (New York: Norton, 1977), 196-204.

9 Erik Olssen, 'Wakefield and the Scottish Enlightenment with particular reference to Adam Smith and his Wealth of Nations', in Edward Gibbon Wakefield and the Colonial Dream: A Reconsideration (Wellington: Friends of the Turnbull Library and GP Publications, 1997), 48.

10 Fernand Braudel, A History of Civilizations, translated by Richard Mayne (New York: Penguin, 1993), 26.

11 Of 105 primary references to New Zealand, only 10 (including three from Dunedin) refer to the South Island; 13 were either non-New Zealand primary or secondary sources. Paul Shepard, English Reaction to the N.Z. Landscape Before 1850, Pacific Viewpoint Monograph No. 4 (Wellington: Victoria University of Wellington, Department of Geography, 1969), 16-49.
} 
utilitarian framework. ${ }^{12}$ In 2000, the historian Giselle Byrnes presented European naming and description of New Zealand within aesthetic conventions as instances of cultural and environmental colonisation. ${ }^{13}$ More recently published works in environmental history have stressed Romanticism's ambiguity, but also pointed out its material impacts on settlement. In separate works from 2014 Jonathan West and I showed that romanticism encouraged preservation of particular kinds of landscapes over others. We also demonstrated that conservation of scenic areas based on Romanticism represented another means by which the settler state both denied Mãori access to their resources and relegated Māori to the historical past rather than the present of colonialism. ${ }^{14}$

Despite recent scholarship in a number of fields on Romanticism, there is a dearth of works on Romanticism and environmental history in New Zealand. Romanticism, this article shows, played a fundamental role in framing settler reactions to and sometimes actions towards Otago's environment from 1840 to 1860.

Otago's settlers relied on traditions of seeing landscapes set during the preceding centuries. During the late seventeenth and eighteenth centuries, specific aesthetic conventions had developed to describe particular kinds of landscapes, as well as the kinds of feelings they ought to evoke. One particularly common Romantic convention-the Sublime-elicited sheer terror. In 1688, John Dennis, climbing a mountain near Lake Aiguebelette in what is now the French Alps, stared aghast at the 'craggy Clifts' swirling in cloud that greeted him and his fellow mountaineers. Later he mused how 'in a litteral [sic] sense' he and his companions had 'walk'd upon the very brink ... of Destruction'. One 'Stumble' would have thrown them to their deaths. This experience evoked 'a delightful Horrour [sic], a terrible Joy, and at the same time, that I was infinitely pleas'd, I trembled'. ${ }^{15}$

The Sublime came to inspire mountaineering, as mountains became places to revel in God's wonderful creation, in the same way in which forests came to stand in for God's natural cathedrals. Edmund Burke's influential book of 1757, A Philosophical Enquiry into the Origin of our Ideas of the Sublime and Beautiful, popularised this aesthetic, by providing a checklist of Sublime scenery designed to elicit the requisite

12 Judith A. Johnston, 'Pictures of a landscape: Images of relief features of New Zealand 1839-1855', in Southern Landscapes: Essays in Honour of Bill Brockie and Ray Hargreaves, ed. Geoff Kearsley and Blair Fitzharris (Dunedin: Department of Geography, University of Otago, 1990), 22.

13 Giselle Byrnes, 'Surveying space: Constructing the colonial landscape', in Fragments: New Zealand Social and Cultural History, ed. Bronwyn Dalley and Bronwyn Labrum (Auckland: Auckland University Press, 2000), 54-75.

14 James Beattie, 'Wilderness found, lost and restored: The sublime and picturesque in New Zealand, 1830s-2000s', in The Future of Wilderness in Aotearoa New Zealand, ed. Richard Reeve and Mick Abbott (Dunedin: Otago University Press, October 2011), 91-105; Jonathan West, 'Running wild: What path will we walk through the wilderness?', in Mick Abbott and Richard Reeve, eds, Wild Heart: The possibility of wilderness in Aotearoa New Zealand (Dunedin: Otago University Press, 2011), 40-50.

15 John Dennis, 'Crossing the alps in 1688', in The Picturesque: Literary Sources and Documents: The Helm Information Literary Sources and Documents Series, volume I: The Idea of the Picturesque and the Vogue for Scenic Tourism, ed. Malcolm Andrews (Bodmin, Cornwall: Helm, 1994), 91-2. 
emotions on the part of the mountaineer or walker. Such books were influential because identifying these coded feelings marked out an individual's education and sophistication, for it was believed that only those with a polished education gained in polite society could appreciate such scenery. With the spread of education in the nineteenth century, Burke's ideas_as well as those of other writers who sought to codify the Sublime and other landscape conventions — enjoyed a popular currency amongst the educated classes, just as natural history came to also. ${ }^{16}$

\section{The Sublime in the Southern Alps}

The mountain range in Otago designated by Europeans as the Southern Alps and Ngai Tahu as Kà Tiritiri-o-te-Moana created the perfect environment in which to delight in the delectable horror of the Sublime. In 1862, the surveyor James McKerrow (1834-1919) and his assistant battled against a storm on the south-west coast. Viewing a landscape seemingly devoid of human presence, they climbed to the top of a mountain peak to get their bearings. ${ }^{17}$ McKerrow recorded that all they 'could see was a most dismal' range 'of snowy mountains that chilled and appalled the senses by their sterile magnificence, but no Caswell Sound'-the object of their search. ${ }^{18}$

The particular landscape represented by the Sublime appeared to Europeans to be a largely unproductive, snowy and precipitous backdrop to the 'smiling farms' on the environmentally altered lowlands. To Māori of course this was a living landscape of gods/ancestors and, while a harsh environment, one in which food could be gathered. ${ }^{19}$ To McKerrow, as for other Europeans at this time, the Southern Alps were also a numinous landscape, because an aesthetic awareness of nature's beauty revealed God's presence in the landscape. ${ }^{20}$ This was particularly true of the Sublime, which emphasised the insignificance of individuals in the vast spaces of God's creation. Lake Te Anau, McKerrow exulted, called 'forth the homage of reverence and awe as the ramifications of its fjords among precipitous mountains are opened out'. ${ }^{21}$

McKerrow implored his fellow colonists not to 'rest content' until they had experienced at first hand:

the magnificence and grandeur of their native country. [Lake] Manapouri[,] with its wooded inlets and peninsulas and fantastic Bays and Coves, and its girdle of high mountains and water falls is a beauty, an inspiration[,] a joy

16 The Romantic Age in Britain, ed. Ford.

17 This was not just ignorance on the part of McKerrow, but a falsity. As with other European trips of exploration, they relied both on Māori guides and also Māori routes.

18 James McKerrow, 'Reminiscences of James McKerrow Surveyor copied from papers supplied to Dr A. H. McLintock', Toitū Otago Settlers' Museum, Dunedin, 15.

19 Anderson, The Welcome of Strangers.

20 Max Oelschlaeger, The Idea of Wilderness: From Prehistory to the Age of Ecology (New Haven and London: Yale University Press, 1991), 99.

21 McKerrow, 'Reminiscences', 13. 
to every beholder ... no brush can ever hope to paint the ever changing and infinite varieties of colouring [of Lake Te Anau] with which the setting sun gilds peak and snow field and glacier, that he seems loath to leave, as he sinks to the west. ${ }^{22}$

Although depicting a far more benign day than that experienced by McKerrow and his companion some 20 years earlier, the dramatic watercolour 'Cathedral Peaks Manapori [sic] Lake' (Figure 1), attributed to Samuel H. Moreton (c.1843/451921), portrays something of the manner in which Europeans viewed as Sublime the Southern Alps. Two figures perch on a precipice surveying a solitary tree. They are dwarfed by the fearsomely vertical wall of mountainside that dominates the image. The watercolour's composition, particularly in the positioning of the outcrop of rocks, as well as its vertiginous aspect and solitary tree, is reminiscent of the work of Salvator Rosa. A seventeenth-century Italian landscape painter, he specialised in portraying wild, isolated scenery, bottomless chasms and, most famously of all, bandits poised atop rocky crags. ${ }^{23}$ Rosa's work subsequently influenced the development of the Sublime and picturesque.

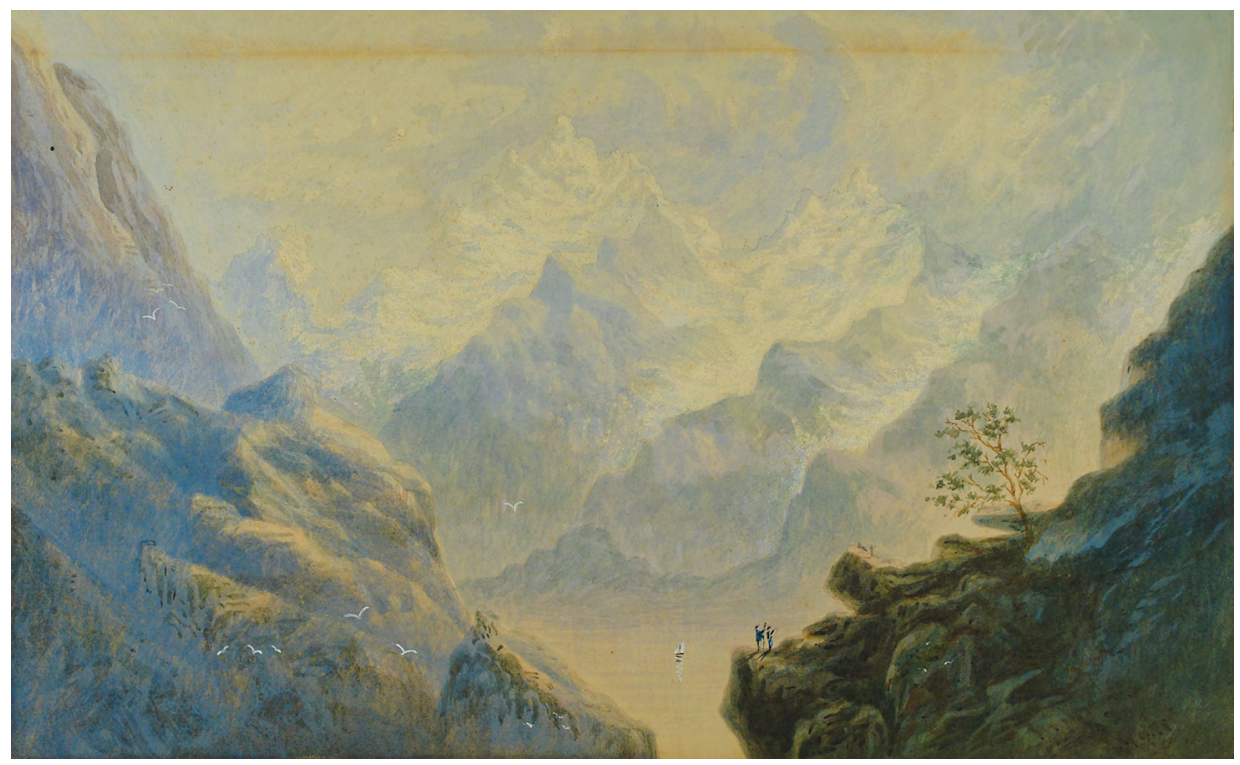

Figure 1: 'Cathedral Peaks Manapori [sic] Lake'. Unsigned, but possibly by S. H. Moreton, 1882. Watercolour on paper, 495 x $305 \mathrm{~mm}$. Donated by Albert Dickison, 1957/27/2.

Source: Toitū Otago Settlers' Museum, Dunedin.

23 Ibid.; Simon Schama, Landscape and Memory (London: HarperCollins, 1995), 453-6 for details and examples of Rosa's work, including his famous Bandits on a Rocky Coast, c.1656. 


\section{Picturesque Otago Harbour}

If Otago's mountains generally elicited responses drawn from the Sublime, then Otago Harbour drew from another convention: the picturesque. Originally meaning 'like a picture', ${ }^{24}$ by the nineteenth century a great debate had developed around the meaning of this concept. To help clarify uncertainty, essayists like William Gilpin (1724-1804) and Sir Uvedale Price (1747-1829) produced guidebooks for wealthy travellers to help them better appreciate parts of the British Isles. As arbiters of art, they labelled some scenes as picturesque and others not, according to their own tastes. The trouble was, none of these authors could agree on a common lexigraphy. While Burke (1729-1797) contrasted the Sublime with the Beautiful, Gilpin and Price regarded the picturesque as closer to the Sublime. And so the debates raged on in this period. ${ }^{25}$ Generally, though, the picturesque came to represent a more watered-down, gentler version of the Sublime. The rugged and negligent Sublime, more or less, came to be contrasted with the roughness and irregularity of the picturesque; the dark and gloomy Sublime juxtaposed against the animated, spirited and variable picturesque. ${ }^{26}$

Alongside these terms, New Zealand settlers seem to have used picturesque in its original meaning to refer to something as being 'like a picture', a description popularly accorded Otago Harbour throughout the 1840s and 1850s. In 1844, the missionary Johann Wohlers (1811-85) described Otago Harbour as 'the most beautiful harbour I've seen':

The mountains ... are formed most charmingly, rising gently and covered with the most beautiful forest green from their feet to the very tops; [the] clear and strong sounds [of] the chorus of the birds from among the bush; the only difficulty here would appear to be the fact that the hills don't leave too much space for a town to be built there. ${ }^{27}$

Significantly, here Wohlers was writing in German: a reminder of the pan-European origins of Romanticism. Other representations from Scots and English-in both writing and images - also draw attention to the attractiveness of forest growing right to the water's edge. In a letter to his fellow minister John $S_{y m}^{28}$ in 1848 , the Revd Thomas Burns (1796-1871) described the Harbour as presenting an 'uninterrupted

\footnotetext{
24 Schama, Landscape and Memory, 6.

25 Andrews, 'Introduction', 34.

26 Based on Uvedale Price and Edmund Burke, in Francis Pound, Frames on the Land: Early Landscape Painting in New Zealand (Auckland: Auckland University Press, 1983), 2519.

27 J. F. H. Wohlers, 'Quarterly reports', translated and transcript, Report no. 1, 16 June 1844. MS-0967/14. Hocken Library, Dunedin.

28 He has not been identified with certainty, but may be the Revd John Sym (1809-1855), minister of the Free Greyfriars Church, Edinburgh.
} 
scene of romantic beauty'. '[S]teep and bold headlands, and peninsulas ... all ... densely clothed from the water up to their very summit with evergreen woods, present $\ldots$ an unrivalled sense of the richest sylvan green and alpine beauty. ${ }^{29}$

An equally lyrical description of Otago Harbour survives in the journal of George A. Hansard, a supernumerary aboard the survey ship Acheron, which charted New Zealand's coastline between 1848 and $1851:^{30}$

A warm and unclouded sun is rapidly bleaching the damp and chilly decks — \& gilds with his rays, every tint from palest to deepest green, within the vast ampitheatre [sic] of wood by which this harbour is encircled. Every mountain, whether flat, round or pyrammidal, [sic] terminates in one unbroken fringe of waving froth. [As they left] ... [s] cores of beautiful gulls alight in [sic] the waves close under the vessel's stern, doing battle with each other for the offal thrown overboard, or perched in dozens upon the waves of seaweed that float by us-many of these islets have scarcely a perceptible motion on the emerald coloured water. ${ }^{31}$

In 1858, the Revd William Johnstone regarded Otago Harbour's scenery as being 'most grand and picturesque', with its trees growing 'up to the very tops of the hills' particularly appealing. ${ }^{32}$ In 1860 settler James Flint, likewise, considered Otago Harbour 'a picturesque looking place', again because of its wooded hills growing right to the water's edge. ${ }^{33}$

By contrast, Ellen Penelope Valpy's (1827-1904) delightful example of what is termed naïve art (Figure 2) impresses with its orderliness and tranquillity. Painted in 1851, three years after the settlement's establishment, this particular viewpoint looking up the harbour from the corner of Manse Street and Princes Street, proved very popular among settler artists in the early years of Dunedin's settlement. A gentle breeze wafts smoke from ill-proportioned cottages in the middle ground; a ship lies lazily at anchor near the shore; two gaily clad figures exchange gossip. The scene, in short, is one of peace and calm: the bush on the peninsula and mainland presents a gentle green backdrop and contrast to the sky and water.

\footnotetext{
29 Revd Thomas Burns to Revd John Sym, Port Chalmers, 25 April 1848, in Otago Journal ([1848]), 39.

30 Long attributed to John Lort Stokes (1811?-1885), captain of the Acheron, Sheila Natusch argues convincingly that the author of the lively journal was none other than the clerk Hansard: Sheila Natusch, The Cruise of the Acheron: Her Majesty's Steam Vessel on Survey in New Zealand Waters 1848-51 (Christchurch: Whitcoulls, 1978), 15-20. Even so, there is still doubt whether Hansard wrote the journal. In T. M. Hocken's handwritten note in the Stokes MS, Hocken believes that the journal was copied by Hansard from Stokes' written copy. For Hocken's comments, see the beginning of John Lort Stokes, 'Journal of the voyage of the Acheron 1849 to 1851', MS Volume 157. Hocken Library, Dunedin.

31 Stokes, 19 April 1849.

32 Johnstone, 29 April 1858, Diary 21 January 1858 - 30 April 1858, in William Johnstone, Papers. MS-993/1. Hocken Library, Dunedin.

33 James Flint, 26 October 1860, 'Journal kept on board ship "Silistria” on the outward passage to New Zealand July 251860 - November 2 1860’. Typescript Misc-MS-0190. Hocken Library, Dunedin.
} 


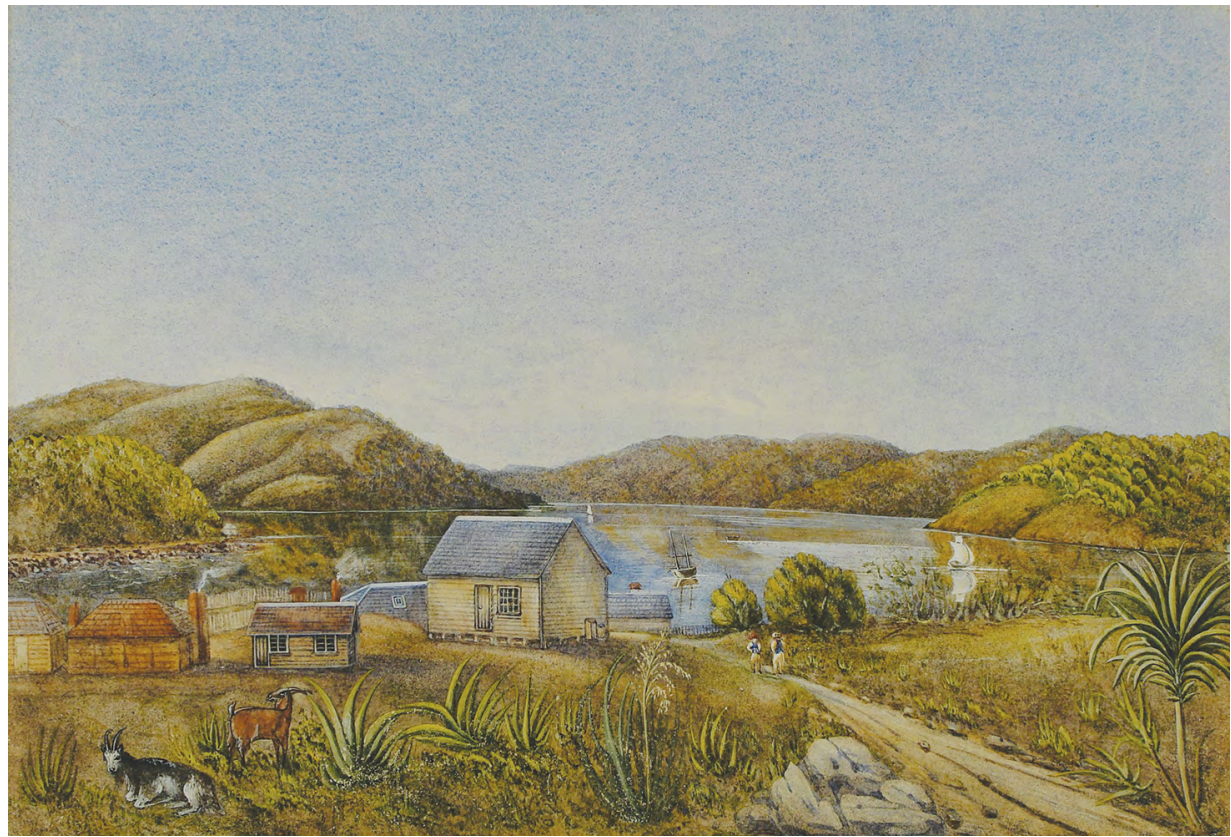

Figure 2: 'John Barton's house, corner Manse Street and Princes Street, Dunedin', by Ellen Penelope Valpy, 1851. Watercolour on paper, CS/1357.

Source: Toitū Otago Settlers' Museum, Dunedin.

A more romantic image of Otago Peninsula (Figure 3) in 1866 appears from the brush of George O'Brien (1821-1888). New Zealand trees frame the view from Kapukataumahaka / Mount Cargill down onto the harbour. Clearly visible are also Hereweka / Harbour Cone (on the right hand side) and Poatiri / Mount Charles. The scene is a peaceful one. The only sense of movement comes from the steamer in the middle plane of the image, a busy contrast to the ships moored nearby.

The deployment of the picturesque and Sublime - and their depiction in artrepresents attempts by settlers to make familiar the unfamiliar, just as they are also statements of ownership that attempt to marginalise manawhenua by overwriting existing names and stories. In analysing image and text, it is clear that few settlers held a purely utilitarian view of the Otago environment-indeed, of the many sources I examined, only four failed to mention Otago Harbour at all. Even William Rich, whose journal entries sometimes amounted to little more than a single word at times, regarded Otago Harbour as a picturesque and wooded place. ${ }^{34}$ But did these aesthetic conventions have any impact on the preservation of certain landscapes or resources?

34 William Gordon Rich, 20 September 1853, 'Diary of a voyage to Auckland New Zealand from England aboard the Joseph Fletcher 17 May 1852 - 31 August 1852 and subsequent life mainly in Otago'. MS 0943a. Hocken Library, Dunedin. 


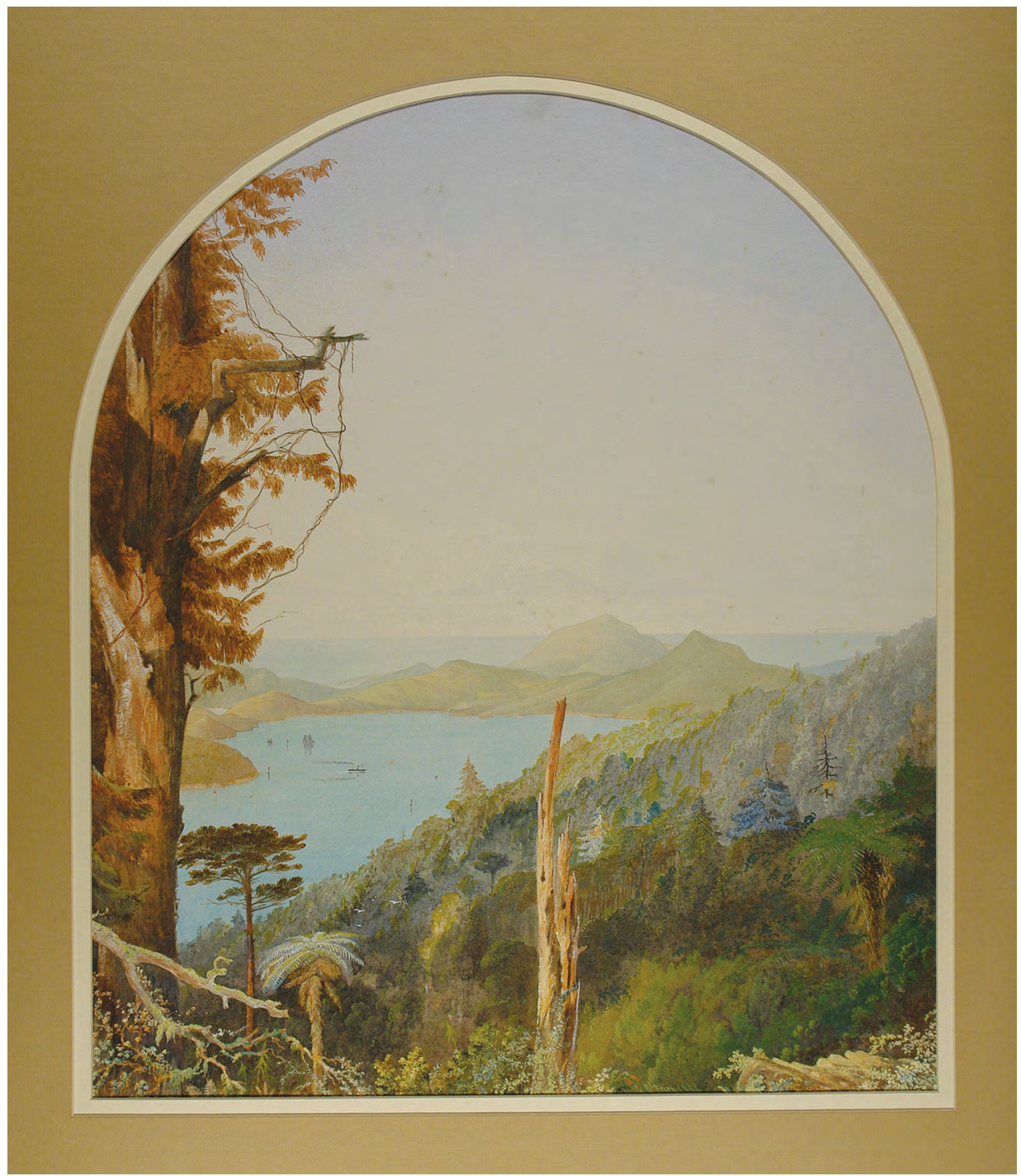

Figure 3: ‘Dunedin Harbour Lower Harbour', by George O’Brien, 1866. Watercolour on paper, $530 \times 447 \mathrm{~mm}$. CS/5426.

Source: Toitū Otago Settlers' Museum, Dunedin.

\section{European conservation in Otago, 1846-60}

There is some evidence of aesthetic concerns prompting forest conservation from the sources I have examined, notably in Dunedin's Town Belt (Section 3). Largely, though, what conservation measures were enacted by the Otago authorities sought to support improvement, to ensure the supply of timber for future generations. The earliest indication of such discussion I have found dates to 1847 , when Colonel 
William Wakefield (1801-1848) wrote to Otago's Chief Surveyor, Charles Kettle (c.1821-1862) of his concerns about 'sawyers cutting timber'. Wakefield suggested to Kettle that cutting 'might be regulated' through the granting of licences 'in certain spots which you can fix'. ${ }^{35}$ Some four months later, in 1848, Kettle recommended to Wakefield that the New Zealand Company (NZC), a chartered colonisation company, prohibit tree felling on its land because builders employed on the 'Maori Reserve' were already accessing NZC timber. ${ }^{36}$ Wakefield also instructed Kettle not to cut timber in Otago, instead arranging for sawn planks to be sent from Nelson Province. ${ }^{37}$

As noted in the first part of this article, published in 2020, Māori had wrought considerable deforestation, especially on the eastern coast of Te Wai Pounamu/South Island. Nevertheless, both Otago Peninsula and, further south, Murihuku/Southland still had considerable tracts of forest. But even on the peninsula, commercial activities associated with the Wellers' whaling station had already occasioned deforestation. In 1839 and 1840, for example, the chief Matapura (fl.1820s-30s) was supplying the whaling station with timber for firewood and building materials, most likely from Sawyers Bay. ${ }^{38}$

NZC officials weren't the only ones who had identified timber scarcity as a problem. In 1852, the Commissioner of Crown Lands, Walter Mantell (1820-1895), echoed Kettle and Wakefield's concerns, by recommending to the colonial secretary the necessity of reserving certain lands 'to preserve the wood from further destruction'. ${ }^{9}$ As the environmental historian Neil Clayton notes: 'From 1851 onwards the dearth of timber had begun to have a direct bearing on land settlement and usage' in Otago. ${ }^{40}$

\section{Timber waste and rival conservation proposals}

The waste of timber raised the hackles of other early settlers, not just the authorities. In 1851 a frustrated Tokomairiro (Milton) settler attacked the 'senseless practice' of ring-barking tōtara (Podocarpus totara). (Ring-barking refers to the removal of the bark around a tree's circumference, resulting in its death.) The writer charged

\footnotetext{
35 [William] Wakefield to [Charles] Kettle, Wellington, 1 November 1847, in Otago Journal ([1847]), 24.

36 [Charles] Kettle to [William] Wakefield, Dunedin, 21 March 1848, 4/46.

37 William Wakefield to Wm Cargill, Wellington, 6 April 1848. Cargill Volume of Correspondence, 1848-53. MS-80. Hocken Library, Dunedin.

38 Peter Tremewan, Selling Otago: A French Buyer, 1840, Maori Sellers, 1844 (Dunedin: Otago Heritage Books, 1994), 23.

39 [Walter] Mantell to Colonial Secretary, 17 May 1852, Otago Crown Lands Correspondence (Outwards), vol. 1, Hocken Library, cited in Michael Roche, A History of New Zealand Forestry ([Wellington]: NZ Forestry Corp. and GP Books, 1990), 67.

40 Neil Clayton, 'Settlers, politicians and scientists: Environmental anxiety in a New Zealand colony', ENNZ 9, no. 1 (2014), www.environmentalhistory-au-nz.org/2014/03/settlers-politicians-and-scientists-environmental-anxietyin-a-new-zealand-colony, accessed 23 July 2021.
} 
that this destructive activity—undertaken by both Māori and Europeans—had 'considerably lessened' the value of land near the Clutha River, about $20 \mathrm{~km}$ south of Tokomairiro/Milton. The waste was considerable and the impact of some magnitude. It takes 'about 60 trees to make one house', the settler declared. If deforestation 'is not checked', the settler warned, 'all the accessible timber will soon be destroyed'. 'The evil', the settler warned, 'requires prompt remedy'. ${ }^{41}$ In 1853, the editor of the Otago Witness, William H. Cutten (1822-1883), echoed such sentiments. Cutten highlighted the 'wasteful process of clearing and burning' the lower reaches of the bush around Taieri Mouth, south of Dunedin and northeast of Tokomairiro/Milton. He also criticised settler practices of selecting the best land, adjacent to timber. ${ }^{42}$ As Clayton notes, Cutten discerned that farming in the Tokomarairo district, and the colony more generally, 'depended on three principal resources: fertile soil, and a supply of wood and water'. ${ }^{43}$

Complaints such as the ones raised by Cutten and the unnamed settler, also writing to the Otago Witness, coupled with ongoing surveyors' concerns, shaped two different sets of land regulations for Otago. Each was discussed in the Provincial Council, and made public in the Otago Gazette and newspapers. The main point of debate was whether to follow a concentrated pattern of settlement, one which accorded with Edward Gibbon Wakefield's (1796-1862) ideals to regulate the price and availability of land and labour (see the first part of the article), or to bow to the realities of Otago and permit pastoralism. Despite such differences of land use, both rival sets of regulations, as Clayton shows, also sought to address problems of timber supply. On one side was William Cargill's plan, which sought to reserve all bushlands within the hundreds, and to release this in lots of no greater than 5 acres ( 2 hectares). ${ }^{44}$ His measures sought to regulate the sale of forestland by controlling 'the supply of bush in proportion to the quantity of open land in question'. ${ }^{45}$

According to Clayton, the rival plan put forward by Englishman John Hyde Harris (1826-1886), one of Cargill's sons-in-law and later Otago's fourth superintendent, better reflected the realities of Otago's varied ecology and its capacity to support different land uses. Hyde Harris's proposal cleaved to the need to reserve forests, too. Of the six different classes of land his proposal recognised, those of 'Timbered' allowed the Waste Land Board to refuse applications for forestland, 'if ... the sale of such land would be injurious to the public interests. ${ }^{46}$ In other words, Hyde Harris's

41 Otago Witness, 21 June 1851, 3.

42 Otago Witness, 19 February 1853, 2.

43 Clayton, 'Settlers, politicians and scientists', 50.

44 'Rural lands were available for purchase, in declared hundreds, at ten shillings per acre, the purchaser to receive the Crown grant upon having effected improvements valued at $£ 2$ per acre.' See G. W. Kearsley, T. J. Hearn and T. W. H. Brooking, 'Land settlement and voting patterns in the Otago Provincial Council, 1863-1872', New Zealand Journal of History 18, no. 1 (2003): 25.

45 Section 6, 13 March 1854, New Zealand Government Gazette (Province of Otago), no. 2, vol. 2 (1854), 38.

46 Section 40, 13 March 1854, New Zealand Government Gazette (Province of Otago), no. 2, vol. 2 (1854), 43-4. 
proposal had much greater flexibility than Cargill's, by permitting the authorities to respond to local vegetation distribution and the requirements of settlers in the allocation of access to forests.

At the foreground of both proposals was a continuing, often confusing and highly acrimonious, set of wrangling between Otago provincial politicians and the Crown. The wrangling drew in Cargill in particular and the Crown's representative in Otago, Mantell, in a fracas that had been going on for over a year prior to the provincial debate, that is, 1853-54. At issue was who had the authority to control the disposal of lands within and outside the Otago Block. Cargill, for as long as he was resident agent for the NZC, had powers to administer lands within Otago. He lost this authority in 1850 when the NZC surrendered its charter (it was eventually dissolved in 1858). In early 1851, the governor appointed Cargill commissioner of Crown lands for the Otago District. Later that year, in October 1851, Mantell became Crown lands commissioner for the Southern District of New Zealand and Province of Otago (1851-55). ${ }^{47}$ The two men were set on a collision course, based on fundamentally different visions for Otago's settlement. Mantell favoured pastoralism. Cargill wanted concentrated settlement. An English-born Anglican, Mantell loathed the Scotland-born Free Church Presbyterian Cargill's perceived favouring of Scottish interests over those, as he saw it, of the common settler. In turn, Cargill baulked at someone whom he perceived as determined to not only dilute but also destroy the religious and settlement ideals of the Otago Settlement.

Matters came to a head in late 1853. Cargill mistakenly believed that his position gave him authority to allocate land anywhere within the boundaries of the Otago Block. Mantell curtly pointed out - correctly_that Cargill's authority only lay within the 144,000 acres $(58,275$ hectares) surveyed and purchased by the NZC. Everything outside that, Mantell declared, was his responsibility. After an acrimonious set of exchanges, and amidst general confusion over Otago land sales, Governor Sir George Grey (1812-1898) intervened, solving the issue by forthrightly dismissing Cargill. ${ }^{48}$ In 1853, Cargill, determined to maintain control over land sales, sought and won the election for the superintendency of Otago Province.

Acrimony spilled over into rival forest conservation proposals. Clayton notes that in late 1854 Cargill rounded on Mantell for 'selling or leasing timber-covered land, regardless of whether or not there was open country available in the vicinity'. ${ }^{4}$ In November 1854, Cargill implored Mantell to put a stop to:

47 [Walter] Mantell to Colonial Secretary, Dunedin, 10 July 1854.

48 On which note: Tom Brooking, And Captain of Their Souls: An Interpretative Essay on the Life and Times of Captain William Cargill (Dunedin: Otago Heritage Books, 1984), and for more specific details: Votes and Proceedings of the House of Representatives, 1854 Sessions I-II, Appendices to the Journal and House of Representatives (Auckland: Williamson \& Wilson for the New Zealand Government, 1855), unpaginated.

49 Clayton, 'Settlers, politicians and scientists'. 
the sale of all Bush Lands in every place where there is any considerable extent of Open Land available for occupation and cultivation with only a small extent of Bush Land in the neighbourhood, and that in no case shall more than one-tenth of any Land sold be Bush Land, until suitable and proper arrangements are made for the proper disposal of Bush Lands. ${ }^{50}$

Mantell ignored Cargill's pleas, and instead pursued his own approach to resource regulation (see below).

Cargill's accusations of Mantell's indifference to the conservation of timber were neither fair nor accurate reflections of the actions taken by the Englishman. They showed, rather, Cargill's dislike of Mantell. Both men, in fact, had a far-reaching appreciation of timber scarcity and of the need to preserve what remained. They simply differed over the means of securing its protection, just as they differed over the kind of settlement pattern for Otago.

\section{The origins of timber concerns}

Where did such concerns arise for both Cargill and Mantell? Clayton has emphasised the importance of Mantell's expedition into North Otago in 1852-53 in alerting him to the dearth of timber and the necessity of forest preservation. ${ }^{51}$ This certainly played a part, yet a close reading of Mantell's activities, through his letter-book as lands commissioner, reveals a much longer and more detailed concern about forest conservation that dates to before this expedition. As an example of the longer duration of such concerns, in early 1852 Mantell served 'Notices' on former whalers living 'at Kuri Woods, three miles North of Onakakura [Waianakarua, North Otago]'. The former whalers, Mantell observed, 'employed themselves in bush farming in a manner very destructive to that beautiful and valuable Grove'. As an additional measure, Mantell 'deemed it necessary to reserve the land between the Kuri and the Kuriwas in order to preserve the Wood from further encroachment'. The Kuri and Kuriwas mostly likely refers to an area of land between two rivers, now known as Big Kuri Creek / Kurinui (or Te Kurī) and Little Kuri Creek / Kuriti. ${ }^{52}$ Mantell went further, recommending the revocation of a 10-acre (4-hectare) timber reserve in Kuri Town Reserve (Hampden, about $80 \mathrm{~km}$ north of Dunedin). This appears to have been land Mantell had set aside for Māori as a Native Reserve under the terms of the 1848 Otago purchase. Mantell recommended either making it a public reserve or disposing 'of the land to the owners of the Timber'. The latter, he felt, 'offers of making the approbation by Government of Natives disposed to

50 New Zealand Government Gazette (Province of Otago), no. 14, vol. 2, 28 November 1854, 1.

51 Clayton, 'Settlers, politicians and scientists'.

52 I sincerely thank Chloe Searle for this information. 
adopt more civilized modes of life'..$^{53}$ If, indeed, 'Kuri Woods' was the Kuri Bush reserve, then it appears that Mantell had reserved it for Māori living at Moeraki in compensation for access to timber which they had forfeited through the laying out of the township of Moeraki, $7 \mathrm{~km}$ from Hampden. ${ }^{54}$

Mantell's actions at Kuri Bush are noteworthy for other reasons, too. They reveal his willingness to censure forest cutters and to set aside timbered land from settlement in response to concerns over future timber shortages. Mantell's comments on the activities of the whalers also gives an insight into methods of bush burn to maintain soil fertility. As the environmental historian Vaughan Wood has demonstrated, many settlers mistakenly assessed bush-covered forest as indicating rich soils and suitable land for farming. In reality, the bounty of Aotearoa's soils lay in the continual cycling of leaf litter and other organic matter into the ground: cut down the forest or scrub and soil fertility declines. ${ }^{55}$ In their adoption of bush-burn agriculture, whalers - many of whom had married Māori and some of whom were of mixedrace heritage - may have adopted traditional Māori methods of cultivation. This relied on the regular firing of forests to provide conditions favourable to the growth of crops. Finally, Mantell's description of the grove as both 'beautiful and valuable' indicates that aesthetic considerations also may have played a role in conservation.

Mantell enforced his intention to protect forests to Europeans as well. In September 1852, he criticised the activities of the Swedish settler Charles Suisted (1810-1860), on his Te Hakapuka / Mount Pleasant run, located near the Otepopo River (now the north branch of the Waianakarua River), about $90 \mathrm{~km}$ north of Dunedin. Mantell noted with concern Suisted's clearing over the preceding years of all but 6 acres (2.4 hectares) of an original 50. Suisted's actions had, in Mantell's opinion, 'proportionally diminished' the value of the property. Accordingly, he charged Suisted 'for clearing so many acres of bush'. ${ }^{56}$ In July 1853, Mantell warned Suisted that he already had had to commence a prosecution 'against certain Sawyers for depredations in the Otepopo Wood'. As a consequence, he wrote to Suisted that:

I find it necessary for the better protection of the Crown property to reserve the Timber of the Otepopo Wood for public purposes of which reservation in accordance with the $41^{\text {st }}$ Clause of the Ordinance of Sept No. 1. I hereby warn you as the licensed occupier of the run in which the said Wood is situated. ${ }^{57}$

\footnotetext{
53 [Walter] Mantell to Colonial Secretary, Dunedin, 17 May 1852. Walter Mantell, Commissioner of Crown Lands, Outwards Letterbook Crown Lands, Southern District of New Zealand and Province of Otago, Nov. 1851 to Dec 1855 inclusive. DAAK/D450/9331/3. Archives New Zealand Dunedin branch.

54 W. H. Cutten, 'Enclosure 1 in No. 20. Chief Commissioner's Report upon Native Reserves', Waste Land Board Office, Dunedin, 14 April 1858, in Alexander Mackay (compiler), A Compendium of Official Documents Relative to Native Affairs in the South Island, vol. 1 (Wellington: Government Printer, 1873), 199.

55 Vaughan Wood, 'Appraising soil fertility in early colonial New Zealand: The "biometric fallacy" and beyond', Environment and History 9, no. 4 (2003): 393-405, doi.org/10.3197/096734003129342890.

566 September 1852.

57 [Walter] Mantell to C. E. Suisted, Dunedin, 30 July 1853.
} 
Here, as earlier with his reservation of Kuri Woods, Mantell was invoking his powers as crown commissioner under the 1849 Land Occupation Ordinance. ${ }^{58}$ Clause 41 enabled the commissioner to reserve timber 'for public purposes'. Clause 39 authorised him to impose a penalty of up to $£ 50$ for any unlawful cutting; if repeated, the offender was liable for a further fine of between $£ 5$ and $£ 50.59$

In 1853, Mantell instituted a further measure designed to control deforestation in Otago - a Central Government licensing system for extraction from areas other than Crown lands reserved for public use. His authority to declare such a measure came from the Crown Lands Amendment and Extension Act (1851). ${ }^{60}$ Issued for a year at a time, each non-transferable licence limited the extent of forest a licence holder could cut. It also prohibited interference 'with a portion of a forest upon which any other person has expended capital or labour'. ${ }^{61}$ Clause 29 prohibited anyone from cutting or removing 'timber on or from the Crown lands which have been reserved by Government for the public use'. ${ }^{62}$ Mantell's action in 1853 appears to have resulted from his earlier observations in Kuri Bush, and, as Clayton notes, more immediately from his inspection tour of 1852-53.

Travelling north from Dunedin in summer, Mantell's summer inspection tour had revealed an alarming lack of suitable timber resources in that region (Table 1).

Table 1: Walter Mantell's assessment of the extent of woodland north of Dunedin, 1852-53.

\begin{tabular}{|l|l|l|}
\hline Acres in scrub & Acres in Copse & Acres in Forest \\
\hline 24 & 27.25 & $50-100$ [all Blackwood at foot of Mt Domett] \\
\hline
\end{tabular}

Source: Enclosure 2: Report on the lower Waitaki from Cape Wanbrow to Pukewhinai December \& January 1852-53, Outwards Letterbook Crown Lands, Southern District of New Zealand and Province of Otago, Nov. 1851 to Dec 1855 inclusive, Walter Mantell, Commissioner of Crown Lands, Archives New Zealand Dunedin branch, C703896.

\section{The Crown and Māori use of forest in Otago}

Mantell, who resigned as commissioner in 1855, had a somewhat ambiguous attitude towards Māori use of forest. On the one hand, for example, in describing customary collection of Tìtì (sooty shearwater, Puffinus griseus), he outlined his 'one objection to these expeditions [as being] the great yearly destruction of Totara Trees of which the Natives use as a covering for the kelp bags in which they preserve

58 Its full title was 'An Ordinance to Regulate the Occupation of Waste Lands of the Crown in the Province of New Ulster (1849)'.

59 New Zealand Government Gazette, No 1, Session 10, 23 August 1849, 315-16.

60 Clauses 13-20, No 10, Session 11, 347-8.

61 Clause 15, 347.

62 Clause 19, 348. 
the Titi'. ${ }^{63}$ On the other, as noted at Kuri Bush, Mantell attempted to allocate timber to those Mãori whose friendship he sought to cultivate. ${ }^{64}$ This latter policy is evident further north, too. At Hakataramea in the Waitaki Gorge, Mantell sought to allow Te Wharekōrari (fl.1848) to continue to have access to 'his cultivations of patches of fertile soil here and there on the islands and the low flats of the rivers'. As a marker of his support for colonisation, Mantell recommended the governor consider granting Te Wharekōrari 'Wheelbarrows and Tools for digging the lignite, fruit trees, quicksets and seeds of trees' ${ }^{65}$

In contrast, Mantell sought to punish Te Huruhuru (c.1800-61) and his followers. Mantell rounded on Te Huruhuru 'and the Punamaru Natives['] ... wanton destruction of the little woods in their neighbourhood'.

They, especially Huruhuru and Takitawine [Te Rakitawine] have devoted days to felling trees which they leave to rot upon the ground being only actuated by a wish to injure the Government which prompted the Waikouaiti Natives they blame for an alleged dishonesty of Te Marama. ${ }^{66}$

Te Huruhuru, as Atholl Anderson notes, had become singularly dissatisfied with the allocation of reserves he had received - a common issue, given the inadequate size of reserves allocated in Otago. ${ }^{67}$ Another, more particular cause, is that, in 1848, while Te Huruhuru was guiding Mantell inland, the former had allegedly 'requested a reserve for firewood'. The reserve was never forthcoming. ${ }^{68}$

The action taken by Te Huruhuru and his people, as alleged by Mantell, in cutting trees, illustrates a common policy of resistance by local peoples to the imposition of colonial resource control, one that rested on the destruction of a resource. ${ }^{69}$ If Mantell sought to use his control over the allocation of resources to try to preserve forest, as well as to reward and punish those Māori whom he deemed to be interfering with the march of colonisation, what then of Cargill? What methods did he use to preserve forests, and why?

63 Mantell to Colonial Secretary, Dunedin, 18 March 1854

64 Mantell to Civil Secretary, Dunedin, 17 May 1852.

65 Mantell records that Te Wharekōrari's 'attachment to Europeans and their customs has acquired for him among the Natives the name of te Pakeha [sic] by which he is generally addressed'. Te Wharekōrari's maps may be viewed at www.kahurumanu.co.nz/ka-ara-tawhito/waitaki, accessed 23 July 2021.

66 Mantell to Colonial Secretary, Enclosure 1, Dunedin, 19 March 1853. Mantell's description of Te Huruhuru contrasted sharply with that of Edward Shortland, who described him 'as a man of singularly pleasing manners and address.'

67 He and his people later settled in Te Waimatemate (Waimate). Athol Anderson, 'Te Huruhuru', Dictionary of New Zealand Biography, first published in 1990. Te Ara-The Encyclopedia of New Zealand, teara.govt.nz/en/ biographies/1t37/te-huruhuru, accessed 12 June 2020.

68 www.kahurumanu.co.nz/ka-ara-tawhito/waitaki, accessed 4 March 2020.

69 Ramachandra Guha and Madhav Gadgil, 'State forestry and social conflict in British India: A study of the ecological bases of peasant protest', Past \& Present 123 (1989): 141-77, doi.org/10.1093/past/123.1.141; Ramachandra Guha, The Unquiet Woods: Ecological Change and Peasant Resistance in the Himalaya (Delhi: Oxford University Press, 1991). 
The historical geographer Graeme Wynn has characterised much of New Zealand's nineteenth-century Pākehā conservation efforts as being led by educated, wealthy settlers. Their capital and experience, education and upbringing, he observes, gave them a long-term perspective on resources and their conservation. ${ }^{70}$ This was also true in this period for another settler group who were educated, but not necessarily wealthy-medical practitioners. A practical training in the sciences, especially in botany and materia medica, furnished medical practitioners with the skills enabling them to recognise and systematically manage resources. In addition, medical training enshrined a strong environmentalist tradition in assessing illness, by strengthening belief in the environmental basis of illness. ${ }^{71}$

Mantell had studied medicine at London University (now UCL), but withdrew before completing his degree, instead, sailing for New Zealand. Mantell's fatherthe renowned palaeontologist and geologist Gideon Mantell (1790-1852)—was a medical doctor who had encouraged Walter to follow in his footsteps. ${ }^{72}$ Walter Mantell's medical training may, then, have furnished him with the skills and interest in forest conservation in Otago.

In considering Cargill's motives for conservation, Clayton also points to the context of post-Enlightenment Scotland in which Cargill grew up as a formative influence. Post-Enlightenment Scotland's emphasis on practicality and wise use, Clayton conjectures, may have helped shape Cargill's interest in forest conservation. This is likely to be correct, but another influence Clayton did not consider was Cargill's experience in India, where he had spent several years. ${ }^{73}$ While Cargill was on the subcontinent, the English East India Company (EIC) instituted early forest conservationist policies, much of which were initiated and managed by medically trained staff. ${ }^{74}$

The EIC conservation connection extended to New Zealand, as a number of early European conservationists in the colony drew from Indian forestry directly or indirectly to push for forest management and reservation. In 1850s Otago, Cargill, the surveyor John Turnbull Thomson (1821-1884), with experience in the Straits Settlements), and John Larkins Cheese Richardson (1810-1878) were all individuals with experience of India or the EIC who promoted forest conservation

\footnotetext{
70 Wynn's work refers to a slightly later, national policy of conservation, but holds true for the earlier period, too. Graeme Wynn, 'Pioneers, politicians and the conservation of forests in early New Zealand', Journal of Historical Geography 5, no. 2 (1979): 171-88, doi.org/10.1016/0305-7488(79)90132-4.

71 James Beattie, 'Natural history, conservation and health: Scottish-trained doctors in New Zealand, 17901920s', Immigrants \& Minorities: Historical Studies in Ethnicity, Migration and Diaspora 29, no. 3 (2011): 281-307, doi.org/10.1080/02619288.2011.577629.

72 M. P. K. Sorrenson. 'Mantell, Walter Baldock Durrant', Dictionary of New Zealand Biography, first published in 1990. Te Ara-The Encyclopedia of New Zealand, teara.govt.nz/en/biographies $/ 1 \mathrm{~m} 11 / \mathrm{mantell}$-walter-baldockdurrant, accessed 18 June 2020.

73 Brooking, And Captain of Their Souls, 14-16.

74 Richard H. Grove, Green Imperialism: Colonial Expansion, Tropical Island Edens and the Origins of Environmentalism, 1600-1860 (Cambridge and New York: Cambridge University Press, 1995).
} 
in the province (see below). ${ }^{75}$ The environmental historian Tom Brooking, Cargill's biographer, has told me that Cargill's concerns about forest conservation arose directly in response to his experience in India, namely, Himalayan deforestation in the early 1840s. ${ }^{76}$ This, intriguingly, was the same motivation for Sir John Cracroft Wilson (1808-1881) to pursue the same cause in Canterbury: Wilson had himself also been involved in early conservation efforts in India. ${ }^{77}$

Cargill had been concerned about Otago's timber resources for some time (see Figure 4). Even before his declaration in 1854, described above, Cargill had invoked his powers to conserve 'the Timber and Underwood of every description' in Otago. In 1850, he prosecuted two unlicensed timber cutters operating on Dunedin's Town Belt - an area of land set aside for recreational purposes. ${ }^{78}$ In the same year, Cargill sent a despatch to Governor Grey outlining his solution for regulating access to timber within and outside the Otago Block. Cargill proposed withdrawing from sale all unchosen rural and town lands of which three quarters or more was covered in bush. Cargill recommended then selling the timbered land to proprietors 'of open lands at 40s. per acre, and in the proportion of one acre of Bush for every 50 acres of open land; and the Suburban Bush, also withdrawn as above, at the rate of 60s. per acre, and in the proportion of half-an acre of Bush for each 10 acres of open land'. For unsold timbered lands, Cargill recommended issuing cutting licences. ${ }^{79}$

A clearer picture of Cargill's motivation for conservation emerges in a letter he wrote in September 1854 in response to concerns raised by members of the Brown family of Anderson's Bay, at the start of Otago Peninsula, about deforestation in their locality. Cargill praised the Browns' letter-now sadly lost from the archives'as eyewitness of the evils that have already occurred from the wasteful and dangerous burnings of Bush and other matters affecting the Supply of the Settlers'. Cargill noted his 'pleasure to find that the views I had entertained and urged upon the authorities for many years past, are by you so entirely coincident'. He implored the Browns to provide any further 'matters of detail' that would aid him in drawing up 'a code of regulations with respect to the Bush laws' ${ }^{80}$ This letter, then, may well have provided the impetus for Cargill's drafting of the 1854 regulations, and the direct concerns he expressed regarding timber supply.

75 There were also several other prominent individuals in other New Zealand colonies from India who espoused conservation, such as John Cracroft Wilson and de Renzie James Brett in Canterbury. James Beattie, 'Tropical Asia and temperate New Zealand: Health and conservation connections, 1840-1920', in Asia in the Making of New Zealand, ed. Brian Moloughney and Henry Johnson (Auckland: Auckland University Press, 2007), 36-57.

76 Personal correspondence, December 2019.

77 Wilson observed that his decision to reserve forestland and to push for state control of deforestation in New Zealand arose while administrating a district bordering the Himalayas whose forests he had attempted to preserve. James Beattie, Empire and Environmental Anxiety, 1800-1920: Health, Science, Art and Conservation in South Asia and Australasia (Basingstoke: Palgrave Macmillan, 2011), 155.

78 Clayton, 'Settlers, politicians and scientists'.

79 [William] Cargill to [Sir George] Grey, Dunedin, 19 March 1851, extract of dispatch 59.50 reproduced in Votes and Proceedings of the House of Representatives, 1854 Session I-II, unpaginated.

80 James Elder Brown, George Brown and George Brown junior (Anderson's Bay), Dunedin [undated, likely to be between 19 and 30 September 1854], in General Outward Letterbook, Otago Provincial Government, 1853-1856. AAAC/D500/702/68, 133-4. Archives New Zealand Dunedin branch. 


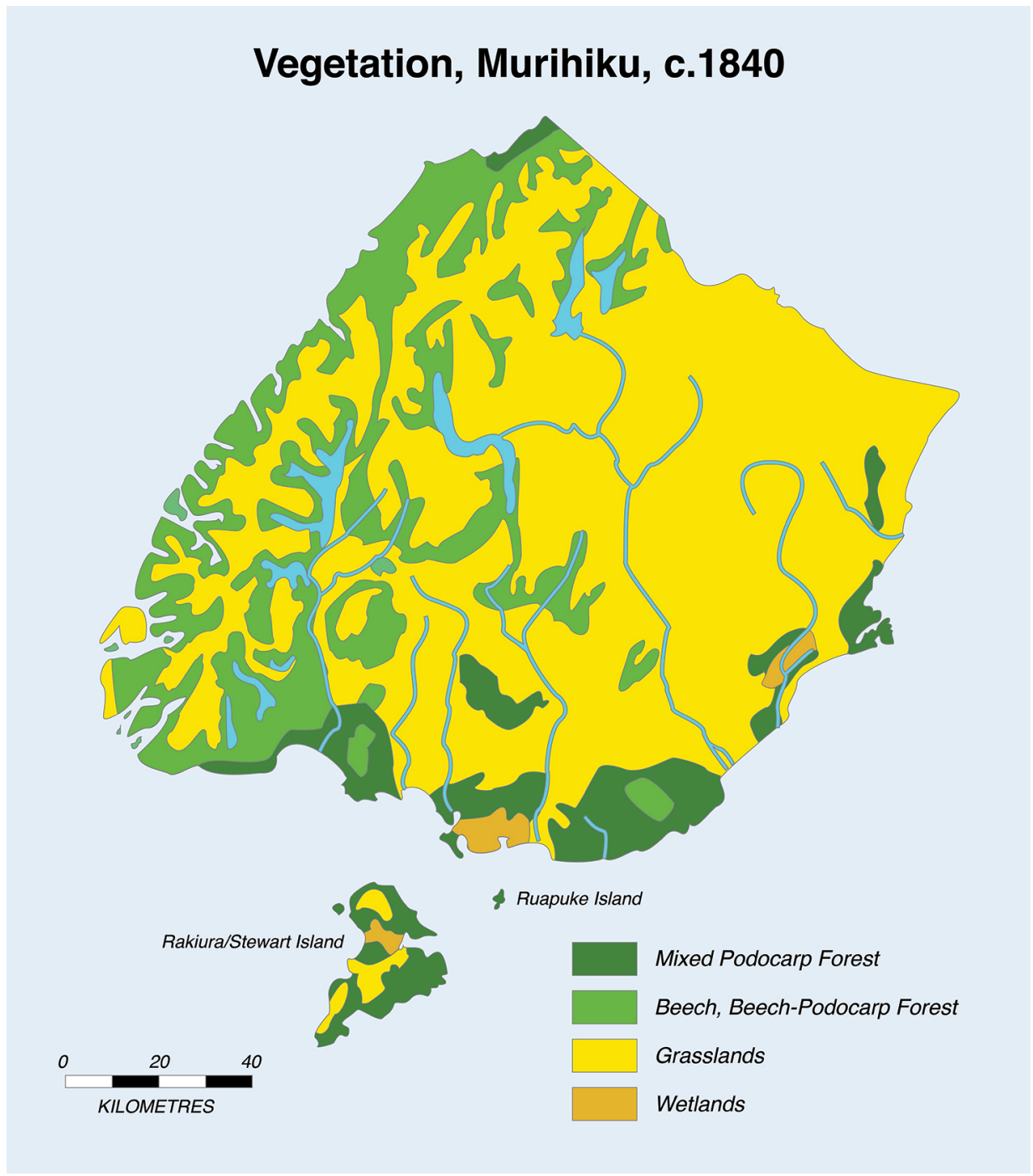

Figure 4: Forest distribution in Murihiku, c.1840.

Source: Author's own, adapted and based on M. A. Bathgate, 'The Maori occupancy of Murihiku, 1000-1900 A.D.: A Geographic Study of Change' (MA diss., University of Otago, 1969), figure 7, 57.

\section{Richardson's proposals}

Cargill, Hyde Harris and Mantell, then, each sought different means of controlling the supply of timber, whether through reservation, licensing or both. A second major alternative approach favoured promoting alternatives, such as hedges or ditches, to timber as a fencing material. 
Richardson recognised the limitations of timber supplies, even though his own property, Willowmead, in Tokomairiro, had considerable groves of forest. ${ }^{81}$ In two lengthy letters to the Otago Witness in July 1858, Richardson outlined the problems of timber supply and consumption besetting the colony. Owing to the scattered distribution of timber and its general inaccessibility in Otago, he observed, 'the available forests are very scarce, and should be carefully husbanded' (See Figure 4). In his overview, Richardson questioned the effectiveness of current land policies. In his opinion, existing policies had allowed settlers to purchase forest blocks, 'instead of attaching portions of it to the adjoining agricultural lands'. Here, Richardson was perhaps echoing Cargill's concerns about the necessity of allocating to settlers both open and forested land. While recognising that 'the evil' the policy created 'is beyond remedy', Richardson put forward two measures. First, he advocated as 'a highly important duty that the Government should appoint wardens to conservate [sic] them [the remaining forests] for the public weal'. Second, he stressed the urgent need to find alternatives to timber fencing, in the form of hedges and earth banks. In his advocacy of conservators of forests, Richardson may well have been following the example of India, with which he was familiar and that, as noted above, had instituted some of the earliest systematic measures to safeguard forests in the British Empire, including establishing a forestry department.

In his far-sighted letters, Richardson considered the broader implications of fencing in relation to Otago's existing and future agricultural needs. Richardson considered 'that our present system of agriculture cannot continue' because it would lead to soil exhaustion. Only a system of manuring, he observed, could save it. This alternative system, he noted, 'involves an organic change, for manure necessitates stock, and stock can only be kept where the rotation system of crops is adopted'. Rotation and fallowing, he observed, would require fencing over a large area. This was because ' $\mathrm{t}$ ] he Hundreds - that sacred commonage which the agriculturist must watch over with a sleepless eye-will ere long be overstocked'. ${ }^{82}$ Here, Richardson was taking a direct swipe at the provisions of concentrated settlement so beloved of Cargill and his supporters, and was recognising the connections between stock, soils and stocking numbers.

Richardson next evaluated the different types of fencing available to settlers, including those made from stone and earth, as well as plain wire. The last he dismissed as 'of doubtful application as regards our somewhat wild herds of cattle'. ${ }^{83}$ In the other part of his letter, Richardson assessed live hedging suitable for Otago- gorse, sweet

81 Richardson, like many others from India and elsewhere, was particularly attracted to New Zealand for the perceived health-giving qualities of its air and broader environment. Richardson wrote a pamphlet specifically targeting EIC migrants who sought out New Zealand. Although provisions existed in the Waste Lands Acts of Otago (and the colony at large) to encourage EIC migration, through the reimbursement of the cost of passage in equivalent land grants, based on rank, it appears that Richardson did not take advantage of such regulations.

82 Otago Witness, 10 July 1858, 6.

83 Ibid. 
briar, elm, privet, holly and hornbeam. For each he described their management and growth rates. For example, gorse, he observed, grows well in 'dry sandy conditions' and produces after three to four years a hedge 'impervious to any animals'. Overall, then, Richardson favoured the promotion of hedging over timber as a long-term solution to Otago's scant timber supplies.

What motivated Richardson? Well-read and wealthy, Richardson conforms to the kind of conservationist described by Wynn. But despite his social station and position as a member of the Otago Provincial Government, Richardson displayed a deep concern for the plight of the common settler and had a ready willingness to support their interests over those of the wealthy. Richardson, as noted, had considerable experience in India, although there is no evidence that this had any direct impact on his attitudes towards conservation in Otago. Practical experience as a settler in Otago also meant that Richardson knew from bitter experience the back-breaking nature of splitting timbers and making fences on his own property, a possible additional factor in his encouragement of live fencing.

\section{Forest conservation and reservation}

What became of the efforts of Richardson, Hyde Harris, Mantell and Cargill? Clayton observes that, following the debate in the mid-1850s, there were no 'further moves to reintroduce timber "conservation" measures' in Otago. ${ }^{84}$ Further research on the Otago Provincial Government papers reveals that this statement is not accurate. During his time as commissioner, as noted, Mantell instituted a system of licensing cutting and reserving timber, a precedent that continued in Otago long after his departure. As the historical geographer Michael Roche observes, likely as a result of Mantell's earlier policies, Otago came to favour forest reservation, rather than timber licensing, as a means of protection. ${ }^{85}$ By 1867 , Roche notes, Otago had over 61,200 acres (c.25,000 hectares) of timber reserves, each mostly of 2.5 to $5 \mathrm{~km}^{2}$ in area. ${ }^{86}$

Issues with licensing and reservation are illustrated in an incident from 1858. Settlers had long identified the Tokomairiro District as having a relative scarcity of timber (See Figure 4) ${ }^{87}$ In 1853 the editor of the Otago Witness, Cutten, noted that in Tokomairiro there was 'but one piece of bush from which they [settlers] can draw their fuel and fencing'. Consequently, ' $t \mathrm{t}] \mathrm{his}$ bush is reserved, and will last them for many years to come. It is much to be regretted', observed Cutten, 'that this system of

\footnotetext{
84 Clayton, 'Settlers, politicians and scientists'.

85 M. M. Roche, 'An historical geography of forest policy and management in New Zealand, 1830-1940' (PhD diss., University of Canterbury, 1983).

86 Roche, $A$ History of New Zealand Forestry, 67.

87 The district comprised about 26,000 acres (c.10,500 hectares). Cyclopedia of Otago \& Southland (Christchurch: Cyclopedia Company, 1905), n.p.
} 
reserving the woods for general use has not been much more frequently adopted' ${ }^{88}$ Cutten clearly supported his father-in-law Cargill's policies, especially when Cutten succeeded Mantell as assistant and, later, chief commissioner of lands.

In 1858 Cutten informed the Waste Lands Board of unlicensed cutting in Tokomairiro Bush. In response, the board resolved to publish the licence holders' names in the local newspaper. ${ }^{89}$ It also went a step further by appointing J. E. Brown 'Conservator of the said Bush' with powers to take action 'against parties committing the offence'. This was James Elder Brown who, some four years earlier, had petitioned Cargill about the problem of deforestation and timber supply at Anderson's Bay, discussed above. In his role as conservator, Brown received $£ 15$ per annum. ${ }^{90}$ (His appointment derived from Clause 76 of the recently passed Land Regulations for the Province of Otago [1858]. ${ }^{11}$ ) I can find no records of what further measures, if any, were undertaken by Brown in Tokomairiro.

The Tokomairiro case underlines Clayton's point that Otago's forests continued to be placed under pressure by further settlement. The 1861-64 Gold Rush heightened timber demand, especially because almost all the main rushes took place in relatively treeless Central Otago. ${ }^{92}$ Driven by economic necessity, most settlers also failed to appreciate the general scarcity of timber in their particular districts. For example, in 1858 settlers in Dunedin's North East Valley agitated for the cutting of the 'Bush lying useless above the' Valley. In part, they did so to alleviate a tight job market in which the government had reduced wages for public works in a period when prices for basic goods remained high. ${ }^{93}$

Nor was such sentiment limited to settlers. The surveyor Thomson gave a public lecture in 1858, based on his reconnaissance of Otago, which fed belief in an inexhaustible resource frontier. ${ }^{94}$ Cutten, the editor of the Otago Witness, captured this mood of optimism, and of a limitless frontier lying at one's doorstep, when he noted that from Thomson's 'very able description, given from actual observation, it would appear that the undeveloped resources of the Province are so extensive that it is ridiculous to suppose a few hundred persons can more than temporarily

\footnotetext{
88 Otago Witness, 19 February 1853, 2.

89 Otago Witness, 20 March 1858, 3.

90 W. H. Cutten to Superintendent, 'Preventing timber at Tokomairiro being cut without a licence', AAACD500707Box129, 97a. Archives New Zealand Dunedin branch.

91 The 1858 regulations were printed in the Otago Witness, 8 May 1858, 9. Essentially, the powers continued Clause 29 from Crown Lands Amendment and Extension Act (1851), mentioned above.

92 Clayton, 'Settlers, politicians and scientists'; James Beattie, "Hungry dragons": Expanding the horizons of Chinese environmental history-Cantonese gold-miners in colonial New Zealand, 1860s-1920s', International Review of Environmental History 1, (2015): 103-45, doi.org/10.22459/IREH.01.2015.05. The exception was in forested Round Hill, Southland.

93 Otago Witness, 7 August 1858, 5.

94 J. T. Thomson, Sketch of the Province of Otago: A Lecture (being one of the series delivered at Dunedin) (Dunedin: W. Lambert, 1858), 12.
} 
overstock the labour market'. ${ }^{95}$ Further European knowledge of the interior of Otago boosted optimism, including evidence of extensive forests in and around what became the city of Invercargill (Figure 4). ${ }^{96}$

While a promoter of development, Thomson, in his earlier work in the Malayan Straits Settlements in the 1840s, had written about the effects of deforestation in increasing temperatures, reducing rainfall and changing hydrology. ${ }^{97} \mathrm{He}$ also wrote about the importance of forest conservation, ${ }^{98}$ and knew about James Richardson Logan's (1819-1869) argument for climate change and the necessity of forest conservation in the Straits Settlements. ${ }^{99}$ This perhaps explains why, amidst a largely euphoric description of Otago's resources, Thomson's 1858 address sounded a note of caution in pointing out that the importance of forest resources would become apparent 'in future times'. ${ }^{100}$

\section{Dunedin's Town Belt}

The authorities faced similar issues of ensuring a balance between short- and longterm development, as well as balancing the needs of the many against the needs of the few, in the management of Dunedin's Town Belt, an area of reserved public land comprising some 300 acres (120 hectares). ${ }^{101}$ In line with NZC precepts of planned settlement, Charles Kettle's plans for Dunedin included a Town Belt, as well as other public reserves (See Part I, Figure 1).

The origins of the Town Belt and other reserves in New Zealand lay in town planning in Victorian Britain, which was only developing at the time of New Zealand's colonisation. ${ }^{102}$ The needs of health and recreation motivated the establishment

95 Otago Witness, 31 July $1858,4$.

96 Paul Star, “Doomed timber": Towards an environmental history of Seaward Forest', in Landscape/Community: Perspectives from New Zealand History, ed. Tony Ballantyne and Judith A. Bennett (Dunedin: University of Otago Press, 2005), 17-29.

97 J. T. Thomson, 'General report on the residency of Singapore, drawn up principally with a view of illustrating its agricultural statistics', Journal of the Indian Archipelago and Eastern Asia 3, no. 2 (1849): 618-28.

98 J. T. Thomson, 'Temminck's general view of the Dutch Possessions in the Indian Archipelago', Journal of the Indian Archipelago and Eastern Asia 1 (1847): 183-223.

99 J. R. Logan, 'The Probable effects on the climate of Pinang of the continued destruction of its hill jungles', Journal of the Indian Archipelago and Eastern Asia 2, no. 2 (1848): 534-6.

100 In 1858, he thought more than 80 per cent of Otago was ideally suited as pastureland. Waste (barren or lake) areas constituted only some 10 per cent of surveyed land, although he estimated four times as much remained unsurveyed. If the 144 square miles (37,300 hectares) of swamp could be drained, Thomson estimated over 90 per cent of Otago's land could be brought into production for either agriculture or pastoralism. Ultimately, Thomson's vision of an Otago economy undergirded by pastoralism would hold sway over Burns and Cargill's vision of a concentrated community of Presbyterians. Thomson, Sketch of the Province of Otago, 12.

101 Otago Witness, 11 July 1857, 2.

102 Tom Brooking, "Green Scots and golden Irish": The environmental impact of Scottish and Irish settlers in New Zealand: Some preliminary ruminations', Journal of Irish \& Scottish Studies 3, no. 1 (2009): 41-60. 
of parks in cities in this period. This was underpinned by the prevailing belief in the environmental basis of diseases, which held that parks and trees removed poisonous air from cities. ${ }^{103}$

The clearest earliest statement of the vision and purpose of the Town Belt comes from the Dunedin Public Lands Ordinance (1854), which set up a Board of Commissioners to manage Dunedin lands 'reserved for public purposes'. Public reserves - from those set aside for education to cemeteries - included 'a Park, and other places for health and recreation in and about the Town of Dunedin'. Clause 16 specifically addressed management of the Town Belt. This enabled the authorities to lease portions of the Town Belt to private citizens (presumably for grazing, as later occurred), but stipulated that provisions had to be:

made for preserving the trees and shrubs thereon, or such part of them as it may be desirable to preserve, with a view to the ornament and amenity of the ground, and also for draining and improving it, and ultimately laying it down in grass, with walks and carriage drives, as a public park or place of recreation. ${ }^{104}$

Finally, the clause permitted only the erection of fences on the Town Belt. Development of the Town Belt as a fully grassed recreation area was never completely realised, possibly because Dunedin Botanic Garden (established in 1863) came to fulfil this role. ${ }^{105}$

While Cargill had envisioned at least part of the Town Belt as a grassed recreation park, others viewed and used the reserve differently. As noted above, issues had already arisen with illegal timber getting-invoking his powers as resident agent, Cargill had had two men charged in 1849. These concerns continued into the 1850s, as well as calls for other uses for portions of the Town Belt. In 1854 the Provincial Government received a petition for parts of the Town Belt to be released to provide extra pasturage for cattle, a request it declined. ${ }^{106}$ The area of the Town Belt was reduced in the 1850s through the development of cemeteries, such as Arthur Street Cemetery and the Northern and Southern cemeteries. In 1857, for example, 31 acres (c.5 hectares) was removed from the Town Belt to create the Northern Cemetery and 28 acres (c.11 hectares) for the Southern Cemetery. ${ }^{107}$

103 James Beattie, 'Colonial geographies of settlement: Vegetation, towns, disease and well-being in Aotearoa/ New Zealand, 1830s-1930s', Environment and History, 14, 4 (November, 2008): 583-610, doi.org/10.3197/ 096734008 X368457.

104 Dunedin Public Lands Ordinance, 1854', Otago Gazette 11 (March 1854), vol. 1, no. 5A, 2-4.

105 The aims of the ordinance, however, represented something of a dead letter, as government deemed its provisions illegal. Passage of the Public Reserves Act (1854), however, confirmed Crown ownership of reserves, but vested the power to manage and proclaim such reserves in the person of the provincial superintendent.

106 Otago Witness, 12 August 1854, 3.

107 Otago Witness, 20 June 1857, 2. 
In 1857, a survey of Otago Province described the manner in which settlers were using the Town Belt. An area 'reserved for the use of the inhabitants as pleasure grounds', the Town Belt 'is mostly covered with timber, and supplies a large portion of the firewood, consumed in the town'. ${ }^{108}$ Clearly, most settlers regarded the Town Belt as a common resource. ${ }^{109}$ In the next decade, an influx of gold miners placed even greater pressure on the Town Belt, as squatting and timber-getting increased. ${ }^{110}$

In 1858, Otago Provincial Council Clerk John Logan wrote a frustrated letter to the deputy superintendent about misuse of the Town Belt. Logan complained 'that several parties have of late erected temporary houses and squatted down on a portion of the Town Belt within a few yards of my place' on Royal Terrace (Figure 5). They:

have already done irreparable damage by cutting down a considerable portion of the Bush on the Belt which served to beautify the place and which hitherto had been carefully preserved by Mr. Chapman [i.e. Henry S. Chapman, the judge] and myself respectively. They have no particular interest in sparing any of the trees[,] having only a temporary end to serve and consequently I now find that only certain portions of the trees which are cut down are used[,] the rest being left to rot and obstruct the passage along the ground. ${ }^{111}$

As well as having illegally erected dwellings, Logan rounded on the squatters for having destroyed the trees. These trees, he thundered, 'served to beautify the place', and had been 'carefully preserved' by him and Chapman. Logan also criticised the settlers for wasting timber, by leaving trees rotting and unused.

An official response to Logan's complaints followed later that month. Issued by Logan himself, a series of public notices stated 'that SQUATTING, as also CUTTING DOWN TREES [sic] upon the Town Belt of Dunedin, are strictly prohibited; and any person hereafter guilty of so Cutting the Trees will be prosecuted as the law directs'. ${ }^{112}$ Although the relevant magistrate's file has disappeared, other prosecutions followed, as revealed by contemporary newspaper coverage of the magistrate's court. ${ }^{113}$ Clearly, Logan's proscriptions were not working. ${ }^{114}$

108 Otago Witness, 11 July 1857, 2.

109 This is ironic and hypocritical, given the attitude of many settlers towards Kāi Tahu communal ownership. Scottish and English settlers, who had experienced land eviction and the reduction of commonage, thus perpetrated the same acts on Kāi Tahu.

110 Clayton, 'Settlers, politicians and scientists'.

111 John Logan to Deputy Superintendent, Royal Terrace, [Dunedin], 10 August 1858. Otago Province Series 6, 245, Micro 414/8, no. 244. Hocken Library, Dunedin.

112 Otago Witness, 28 August 1858, 3. This notice was repeated in Otago Witness, 4 September 1858, 8.

113 For the later history of the Town Belt, see: James Beattie, 'Battle for the belt', Forest \& Bird Magazine 378 (2020): 60- 1 .

114 In 1865, for example, the Dunedin magistrate fined Mary Farquaharson $£ 2$ and costs, noting that 'he was very glad to see that the citizens were now coming forward and assisting the police to put a stop to the practice of destroying timber on the Town Belt'. The complainant, Alfred Talbot, related that ' $\mathrm{h}$ ] e had frequently seen her cutting down trees on the Town Belt', warning her on several occasions. Otago Daily Times, 13 October 1865, 5. I thank Austin Gee for finding this material. 


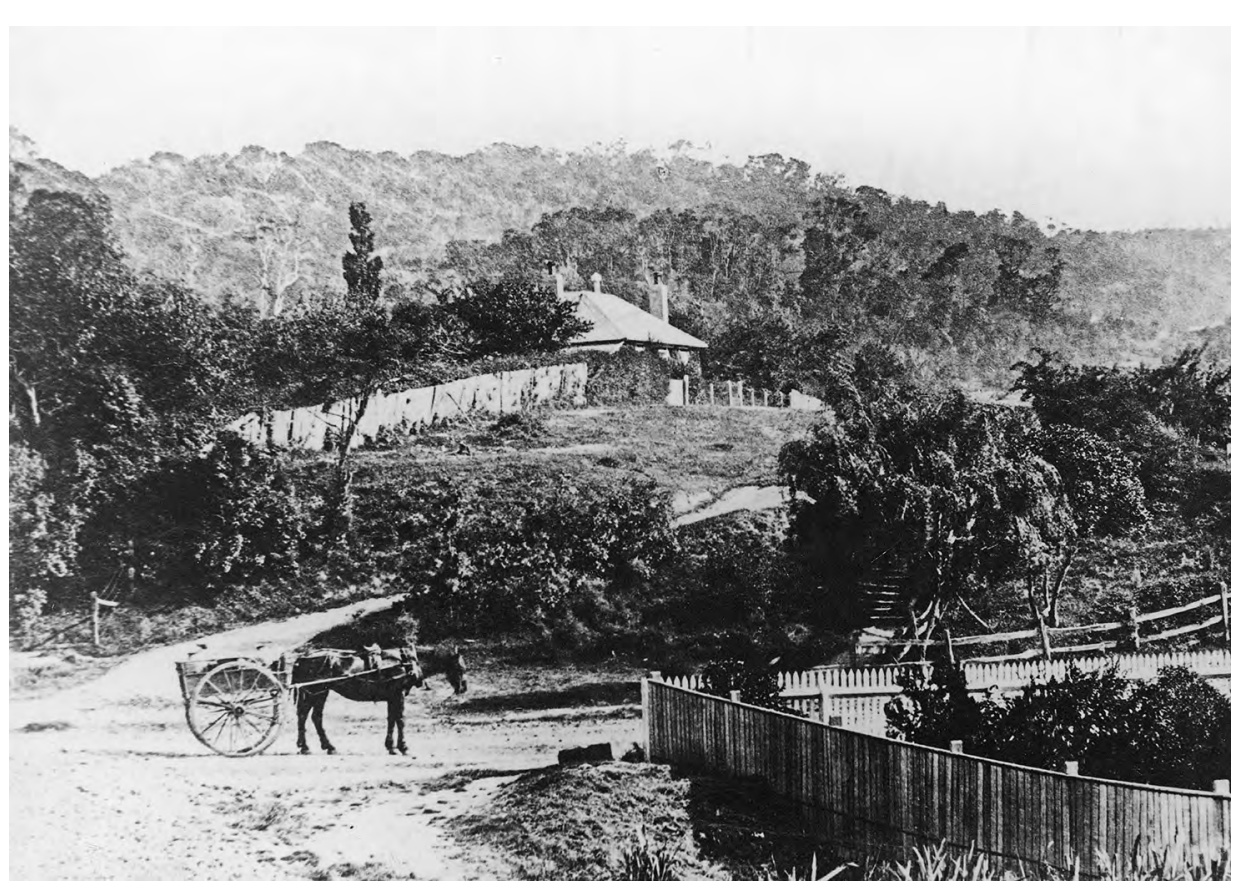

Figure 5: Fern Tree Cottage (Violet Grove, Royal Terrace, Dunedin), no date (c. late 1850s / early 1860s). Photograph CS/13752.

Source: Toitū Otago Settlers' Museum, Dunedin.

Logan's observations illustrate that conservation of areas on grounds of beauty occasionally existed alongside, or even above, utilitarian concerns. In his 1858 report, Thomson also presented a case for the preservation of unique geological features, another popular concern of romantics. Thomson urged that Moeraki boulders-large spherical boulders - 'though of no utilitarian interest', must be protected because of their rarity. ${ }^{115}$

\section{Conclusion}

Despite ushering in profound environmental changes to the soil, water and vegetation of Otago, European settlers were indifferent neither to the environment around them, nor to the effects of their own actions on it. One common way in which settlers encountered the Otago environment was shaped by Romanticism. This gave settlers a framework within which to place various parts of Otago's environment, whether the picturesque wooded sides of Otago Harbour or the Sublime, awe-inspiring scenery of the Southern Alps. Their perspective was manifestly not an ecological sense of interconnected species and their environments. Nor was there necessarily

115 Thomson, Sketch of the Province of Otago, 12-13. 
an awareness that changes made to one part of an ecosystem would invariably cause changes to the whole-although Richardson came close in recognising the connections between timber supply, stocking rates and soil fertility. Still less was there much of an appreciation or awareness of the mosaic of Māori foodways that existed prior and during colonisation. The aesthetics settlers imposed over Māori names and understandings of whenua reflected the particular time and place of the European cultures in which these ideas were forged.

A deep sense of regret at the loss of the environments they had first encountered as immigrants would often only emerge at the end of a settlers' own lifetime, as they had borne witness to the rapid depletion of forests or the disappearance of birds. Instead, from the late 1840 s it was largely fear of resource scarcity that drove the authorities to conserve forests, license timber-getting or appoint forest guardians. The ideals of Romanticism also fired the establishment of reserves like Dunedin's Town Belt, which many settlers valued as places of wilderness to inspire care-worn city dwellers both through their beauty and the recreational opportunities they offered. Romanticism also fired efforts by settlers such as John Logan to protect the Town Belt's beautiful trees from destruction. In this complex postlapsarian world of Otago, it is clear that settlers were far from exhibiting indifference to the natural world. They in fact found much beauty and solace in the environment of their new home, expressing pleasure in its appearance just as they went about changing it. 
This text is taken from International Review of Environmental History, Volume 7 , Issue 2, 2021, edited by James Beattie, published 2021 by ANU Press,

The Australian National University, Canberra, Australia.

doi.org/10.22459/IREH.07.02.2021.04 